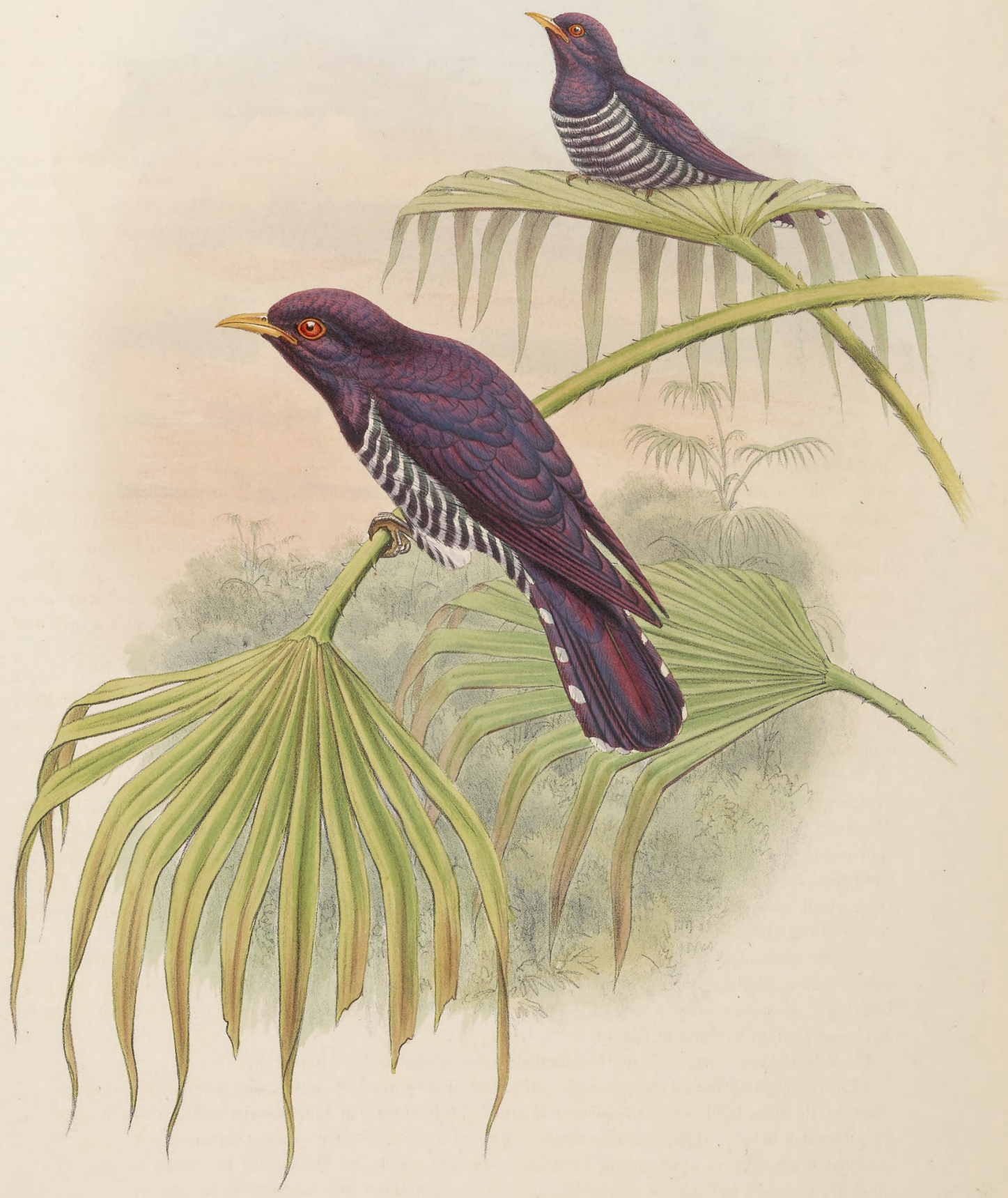




\title{
CHALCITES XANTHORHYNCHUS.
}

\author{
Amethystine Cuckoo. \\ Cuculus xanthorhynchus, Horsfield, Transactions of the Linnean Society, xiii. p. 179 (1821). -Id. Zool. \\ Researches in Java, pl. 59 (1824).-Müller, Verhandel. Natuurl. Geschied. Land- en Volkenk. p. 234, \\ note 6 (1839-44).-Gray, Genera of Birds, ii. p. 463 (1847).-Schlegel, Mus. Pays-Bas, Cuculi, \\ p. 32 (1864).-Gray, Hand-list of Birds, ii. p. 219 (1870). \\ Chrysococcyx xanthorhynchus, Blyth, Journal of the Asiatic Soc. Bengal, xxi. part 1, p. 245 (1843). - Id. Cat. \\ Birds Mus. Asiatic Soc. Bengal, p. 73 (1849).-Bonap. Consp. Gen. Av. i. p. 106 (1856).--Horsfield \\ \& Moore, Cat. Birds Mus. E.-I. Co. ii. p. 706 (1856).-Sclater, Proc. Zool. Soc. 1863, p. 209.-Salva- \\ dori, Uccelli di Borneo, p. 62 (1874).-Blyth \& Walden, Birds of Burmah, p. 80 (1875).-Hume, \\ Stray Feathers, 1874, p. 191, 1875, p. 81. \\ Chalcites santhorhynchus, Hartlaub, Verz. Mus. Bremen, p. 97. \\ Lampromorpha santhorhynchus, Bonap. Consp. Vol. Zygod. p. 7 (1854). \\ Chalcococcyx xanthorhynchus, Cabanis \& Heine, Mus. Hein. Th. iv. p. 15 (1862).
}

This elegant little Cuckoo was first discovered by Dr. Horsfield in Java, and since that time its range has been much extended by subsequent travellers, for it has been recorded from Sumatra and Malacca, whence it ranges as high north as Burmah. Here it is stated by Mr. Blyth to have been procured by Helfer "probably in Mergui province." Mr. Hume has recorded it from T'enasserim, and also from the islands of the Bay of Bengal. It has also been procured in several parts of Borneo, as, for instance, at Banjarmassing by Motley, at Pontianak by Diard, and at Sarawak by Doria and Beccari. Mr. Sharpe informs me, moreover, that Mr. Hugh Low obtained two beautiful adult birds from Labuan shortly before his departure from the island; it was quite unknown to his native hunters, and was evidently a rare bird there, never having been observed before by him during a long residence.

With regard to its occurrence in the Philippines there is at present some uncertainty, Mr. Vigors having in 1831 described a Cuculus amethystinus. On this subject the Marquis of Tweeddale writes:- "Mr. Blyth in 1842 (J. A. S. B. xii. 1. p. 245) expressed himself unable to see in what the Philippine Amethystine Cuckoo, as described by Vigors (l.c.), differed from the Javan and Malayan species, and in his 'Catalogue of the Calcutta Museum,' no. 354, identified the two forms under Horsfield's title. But there is no evidence that examples had been compared, and no Philippine example was contained in the Calcutta Museum. All subsequent authors appear to have followed suit, yet without having compared actual specimens. In the 'Conspectus' (i. p. 107) Bonaparte united the two titles, and even left out the Philippine habitat. Dr. Cabanis, Horsfield and Moore, Dr. von Martens, Professor Schlegel, and Mr. G. R. Gray all made the same identification, and yet no Philippine examples are recorded as being preserved in any of the Museums these authors had access to."

Cuculus xanthorhynchus, Horsf., extends to Borneo, and it is therefore not of itself improbable that it also occurs in Luzon; but as there is no positive evidence of the fact it is best to keep the two titles separate until the contrary is proved. Following Lord Tweeddale's course I have not added the synonyms of $C$. amethystinus to those of the present species.

The following is a transcript of Dr. Horsfield's description in the 'Researches':-

"Entire length six inches and one half. Head and upper parts deep brown, with a beautiful violet reflexion, which in a certain light exhibits a metallic lustre; quill-feathers and four exterior tail-feathers on each side deep blackish brown; three exterior feathers banded with white; the smallest is tipped with white at the end, and the bands are nearly equal in breadth on both vanes; on the second the bands on the external vanes are broader, and on the third they are greatly contracted and confined to the exterior vane. The breast, abdomen, thighs, and axillæ are pale ferruginous, and marked with regular transverse bands of deep brown, on which a metallic lustre is occasionally perceptible. The plumes of the front and crown of the head are capable of being elevated to a very slight crest."

According to Beccari's original notes the soft parts are coloured as follows :-

"Iris blood-red; bill yellow, orange towards the base; eyelids red."

The principal figure in the accompanying Plate represents an adult bird of the natural size. 


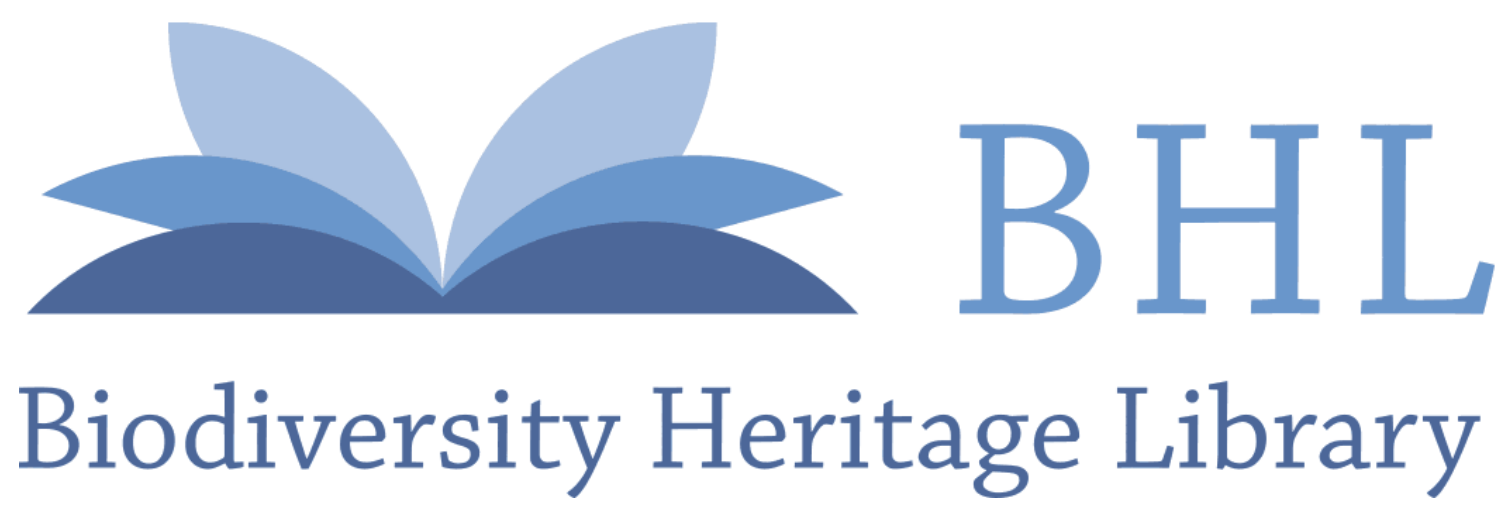

Gould, John. 1877. "Amethystine Cuckoo, Chalcites xanthorhynchus [PI. 47]." The Birds of Asia 6(XXX), -. https://doi.org/10.5962/p.323294.

View This Item Online: https://www.biodiversitylibrary.org/item/122488

DOI: https://doi.org/10.5962/p.323294

Permalink: https://www.biodiversitylibrary.org/partpdf/323294

\section{Holding Institution}

Smithsonian Libraries

\section{Sponsored by}

Smithsonian Institution Libraries

\section{Copyright \& Reuse}

Copyright Status: Not in copyright

This document was created from content at the Biodiversity Heritage Library, the world's largest open access digital library for biodiversity literature and archives. Visit BHL at https://www.biodiversitylibrary.org. 